\title{
The Effect of Online Consumer Interaction and Shopping Motivation on Purchase Intention
}

\author{
Kunthi A Kusumawardani ${ }^{a^{*}}$, Poppy Purniasari ${ }^{b}$ \\ ${ }^{a}$ School of Business, President University, Bekasi, Indonesia \\ ${ }^{\mathrm{b}}$ Faculty of Business, University of Hertfordshire, Hatfield, United Kingdom \\ "kunthi.kusumawardani@president.ac.id
}

\begin{abstract}
Consumer interaction has become more critical than ever. The interaction may happen on various platforms, for instance, brand webpage and social media. This study examines consumer interaction and shopping motivation on purchase intention mediated by EWOM, brand awareness, and brand attitude in the beauty products context. After gathered 300 valid respondents, this study used Structural Equation Modelling (SEM) to analyze the data. The results showed that purchase intention is influenced directly by E-WOM, opinion seeking, annoyance, and brand attitude. Besides, brand page commitment and annoyance influence purchase intention, mediated by E-WOM. Interestingly, viral advertisement, brand awareness, and brand page commitment do not influence purchase intention directly. Research implications and directions for future studies are discussed.
\end{abstract}

Keywords: Opinion Seeking, Viral Advertisement, Annoyance, Brand Page Commitment, Hedonic, Utilitarian, Brand Awareness, Electronic Word of Mouth, Brand Attitude.

\section{Introduction}

Social media is the most sophisticated invention in the $21^{\text {st }}$ century that has removed communication barriers and create a decentralized communication channel (Patil, 2015). Social media is used as a platform for people to communicate, share ideas, bridge the gap of communication, information source, and crucial tool for marketing, especially interacting with the customer (Baruah, 2012). Based on Forbes, there are 4.02 billion internet users around the globe, with active users up to 3.2 billion or equal to $42 \%$ of the world's total population (Shaw, 2018). With the rapid development of online communication, the popularity and level of engagement between social media users have grown (Perreault \& Mosconi, 2018). Companies see this phenomenon as an opportunity to approach customers and tools to offer their products/services (Chandrasekara, 2015). Social media marketing can also act as a bridge between customers and brands (Paquette, 2013). Marketers, therefore, use social media as an element of their marketing campaign (Leung, Bai, \& Stahura, 2015).

The tactic of rapidly propagating media marketing information at a lower cost is through viral advertising, also known as electronic Word-Of-Mouth (e-WOM) (Koch \& Benlian, 2015). Viral advertising happened when social media users share their opinions and recommendations through digital content and influence other users' purchasing decisions and their views on companies (Fransen, Verlegh, \& Smit, 2015). Four major industries, such as healthcare, financial, travel, and retail industries, feel the most benefits from social media marketing (Distaso, 2017). Based on Business Insider, the top 500 retailers in the world earned approximately \$6.5 billion in revenue in 2017 from social media advertising (Pandolph, 2018). Around $72 \%$ of 2000 Instagram users surveyed say that they purchased fashion, beauty, or stylerelated products after seeing them on social media. The most bought categories were clothes, cosmetics, shoes, and jewelry (Salpini, 2017).

As of January 2018, Indonesia occupied third place with the most internet users in the Asia Pacific, with 132.7 million users (Baron, 2018). Businesses like the cosmetics industry have learned to make online marketing their competitive edge (Chattaraj, Mazumder, \& Lahiri, 2018). While the demand for personal care and cosmetics in Indonesia such as skincare, makeup, hair care products consistently grew 10-15\% per annum (Cheong \& Michalski, 2016). Cosmetics brands triumph over digital marketing by using three popular methods, the first one 
they applied search engine optimization to understand their market based on the user's search trace. Second, employ an influencer-driven approach to reach digital-savvy shoppers. Third, make sure the official web page is user-friendly and has fewer struggles to help customers be more confident in purchasing after exposure to several influential contents (Grosman, 2018). Based on the previous study, the impact of e-WOM on consumers' purchase intention in social media has been known significantly (Jamali \& Khan, 2018). Besides, brand page commitment that builds a long-term relationship between the Brand and its consumers positively impacts customers' purchase of the products. Moreover, hedonism and utilitarian as the determinant of brand attitude influence purchase intention (Lou \& Koh, 2016). One of the examples of hedonism is people willing to purchase a product because of pride and the fear of missing out. On the other hand, utilitarian is known to be more based on rational necessity and the good value of money (Mundel, Huddleston, Behe, Sage, \& Latona, 2018).

Marketers use a smart visual content strategy to make social media talks about their products (Stemler, 2015). The more people talk, the more they discover (Hayes, Shan, \& Applequisr, 2016). Campaigns nowadays must consider what is right for different platforms and draw on brand recognition and brand page commitment to improving purchasing intention (Jesse, 2016). The hesitation of purchase is caused by annoyance (Jamali \& Khan, 2018), which can be in the form of repetitive advertisement (Hsu \& Pann, 2017). Besides electronic word of mouth (Tariq, Abbas, Abrar, \& Iqbal, 2018), consumer purchase intention increases by viral advertisements that are spread rapidly (Vianna, de Mesquita, Linhares, \& Moreira, 2016). The availability to seek opinion is also important to increase purchase intention in e-commerce (Cong \& Zheng, 2017).

Similar to the previous research (2018), which examines factors affecting Samsung customers' purchase intention, this research investigates factors affecting cosmetic products' purchase intention. Jamali \& Khan (2018) examined several independent variables; viral advertisement, opinion seeking, annoyance, and brand page commitment. Furthermore, this study investigates further by adding brand attitude, brand awareness, and E-WOM as the mediating variables to get a more comprehensive framework. Besides, this study also includes attitudinal aspects, such as hedonic and utilitarian, as the independent variable. Lou \& Koh (2016) stated that attitudes such as like or dislike toward an advertisement could be a unidimensional construct.

\section{A. Consumer Interaction}

Consumer interaction could be generally characterized as any action taken by a person that affects the valuations or decisions of other consumers concerning a product or service (Wang \& Yu, 2017). In addition, this research concentrated exclusively on opinion-seeking, viral ads, brand page commitment, and annoyance as part of customer interaction (Gunawan \& Huarng, 2015).

\section{Opinion Seeking}

The search for an opinion is a state in which customers search for opinions posted by others on the Internet for some endorsed claim (López \& Sicilia, 2014). This behavior is part of the physiological need of the human being, which provides pleasure and helps to make better decisions (Hutter, Hautz, Dennhardt, \& Füller, 2013). Social networking users include looking for feedback, suggestions, or product recommendations from other related users in the buying decision-making process (Yunus, Ariff, Som, Zakuan, \& Sulaiman, 2016).

Social media users who are in touch with other users tend to seek their views (Jamali \& Khan, 2018). The actors who often influence opinion-seekers to uncover new and unusual knowledge are called opinion leaders and influential people (Ma, Lee, \& Goh, 2015). The 
184 Author Et Al. (2021) The Effect of Online Consumer Interaction and Shopping Motivation on Purchase Intention

position of opinion-seeking has broader implications for both advertisers and promoters. The past investigation presented evidence of a similar construct "opinion-seeking" positively affects purchasing intention (Pandey \& Khare, 2015).

H1: Opinion seeking influences purchase intention.

2. Viral Advertisement

Viral advertising is a message that travels like fire through the social media network (Jamali \& Khan, 2018). Viral advertising is an innovative promotion method that allows people to spread network messages (Vianna, de Mesquita, Linhares, \& Moreira, 2016). People who share a common interest may meet and interact with one another. It will encourage the trial, acceptance, and use of products and services (Trivedi, 2017). Hence, because it offers, viral ads are often chosen by marketers as a method to promote a product or service.

Viral advertising is assessed by source credibility, source convenience, and respectable source of product information (Trivedi, 2017). In addition, a positive commitment to brands will stimulate customers to take advantage of or suggest a social media viral advertisement campaign (Jamali \& Khan, 2018). A much-exposed viral promotional campaign allows the consumer to share favorable knowledge about the goods and services that have been proven to affect his or her buying intention (Vianna, de Mesquita, Linhares, \& Moreira, 2016).

H2: Viral advertisement influences purchase intention

\section{Brand Page Commitment}

A brand page engagement concept depends on the idea of a client's obligation and relates to a good consumer partnership and a passionate connection with a brand page (Shi, 2014). Brand page commitment is essential to building good relationships between customers and companies (Zhang, Benyoucef, \& Zhao, 2016). Because of which the customer feels connected explicitly to the brands. It has a profound positive effect on the minds of consumers (Jamali \& Khan, 2018).

Commitment can be influence by strong sense relationships (Shi, 2014), brand community support (Tajvidi, Wang, Haijli, \& Love, 2017), and brand loyalty (Zhang, Benyoucef, \& Zhao, 2016). A previous study shows that the commitment of the company page has a positive impact on electronic word of mouth (Siswaningsih \& Halim, 2018). Brand page commitment convince the customer to interact with each other (Hutter, Hautz, Dennhardt, \& Füller, 2015). Besides, the dedication of the brand page also has a positive impact on electronic word of mouth (Siswaningsih \& Halim, 2018). According to previous studies, even in low involvement situations, it has been shown that brand-page dedication affects brand recognition (Siswaningsih \& Halim, 2018). Brand page commitment is an important determinant to reach brand awareness (Pappu \& Quester, 2016).

H3: Brand Page Commitment Influences E-WOM

H4: Brand Page Commitment influences purchase intention

H5: Brand Page Commitment influences brand awareness

\section{Annoyance}

Annoyance is the uncomfortable passionate reaction to abstract overexposure to a particular form of media (Tanttu, 2017) and triggered by content in a campaign ad that you would not want to see (Jamali \& Khan, 2018). Ads can be annoying in a few ways, such as popup ads, distracting from important or outstanding work, or even disturbing certain activities entirely. It is uncertain if this disruption is being passed to the marketed brands (Bell \& Buchner, 2018)

Web users may feel irritated by various factors, such as a sense of intrusion and repetitiveness of ads or an excess of exposure to advertised content (Hutter, Hautz, Dennhardt, 
\& Füller, 2015). In addition, pop-up advertising banners and floating advertisements on the side of the web page often influence irritation (Hsu \& Pann, 2017). The frustration with brands published in social media material confirms that they negatively impact WOM (Tanttu, 2017). Annoyance leads to electronic word-of-mouth avoidance, message skepticism, and reduced advertising value (Gvili \& Levy, 2016). Brand awareness can be very intricately linked to the intensity of ads received and processed by the customer. However, the results indicate that growing brand awareness is significantly hindered by annoyance (Wulandari, 2017). Advertisements with greater exposure were more annoying and better remembered than those with less exposure (Kronrod \& Huber, 2018).

H6: Annoyance influences E-WOM

H7: Annoyance influences purchase intention

H8: Annoyance influences brand awareness

\section{B. Shopping Motivation}

Shopping motivation is the foundation of a profitable transaction and allows customers to buy repeatedly (Yeh, Wang, \& Yieh, 2016). A simplified but universal two-dimensional value model composed of utilitarian and hedonic components is developed (Gallarza, Arteaga, Chiappa, \& Irene Gil Saura, 2017).

\section{Hedonic}

Hedonic purchase is stated as "a high inclusion circumstance, where any single people have a profound fall into the consumption occasion" (Khuong \& Tran, 2015). Hedonic consumption provides sensual satisfaction, excitement, and shopping pleasure on its own (Seo, Yoon, \& Vangelova, 2015). In other terms, hedonistic value is created by shopping experience pleasure (Lee \& Wu, 2017).

Hedonic customers are affected by the experience, passion for entertainment, pleasure, and satisfaction (Rezaei, Ali, Amin, \& Jayashree, 2016; Lee \& Wu, 2017). In addition to finding the uniqueness of the shopping experience, hedonic customers are often determined by interactions (Etemad-Sajadi \& Ghachem, 2015). A prior study found that social media brand content is restricted to entertainment-oriented, that users respond more to brand content than to embedded brand details. Therefore, hedonism has a positive impact on the brand attitude directly (Lou \& Koh, 2016). Hedonic consumers significantly develop more favorable attitudes and higher intentions to buy luxury products (Lacroix \& Jolibert, 2017). In addition, hedonic motivation is proven to influence behavioral intention significantly when the customer found an entertainment value in the service offered (Widyanto, Kusumawardani, \& Septyawanda, 2020).

H9: Hedonic influences brand attitude

\section{Utilitarian}

Utilitarian customers want an efficient, balanced, and task-oriented effort related to purchasing products (Anderson, Knight, Pookulangara, \& Josiam, 2014). In a complex shopping situation, the utilitarian value of customers can only find appropriate goods and services that create a perception of value rather than treating shopping as a pleasing task (Lee $\& \mathrm{Wu}, 2017)$. Consumers seeking utilitarian value, therefore, regard shopping as a job. Utilitarian benefits are reasonably concrete and relate to productivity, utility, and economy (Wang E. S.-T., 2015).

Utilitarian customers are defined by a variety of internal variables, which are: performance, comfort, function, and realistic (Lee \& Wu, 2017; Moon, Awanc, Attiqd, Rasool, $\&$ Kiran, 2017). Since users may connect with companies and other users via brand content to obtain additional brand information, customers significantly evaluate these contents to help 
186 Author Et Al. (2021) The Effect of Online Consumer Interaction and Shopping Motivation on Purchase Intention

them obtain brand information. The utilitarianism aspect of the attitude towards brand material positively affects the brand attitude (Lou \& Koh, 2016). Data shows the characteristic utilitarian effect attitude towards the Brand (Zablocki, Schlegelmilch, \& Houston, 2016).

H10: Utilitarian influences brand attitude

\section{Electronic Word Of Mouth}

The appearance of the Internet makes it possible for customers to search the web page (Jalonen \& Jussila, 2016) to obtain information about the product provided by various consumers and to learn how to share it, as demonstrated by their involvement, considerations, and this type of electronic word of mouth (Cong \& Zheng, 2017). Electronic word of mouth implies any positive or negative expressiveness produced by future, current or past clients of an item or organization via the web (Yusuf, Hussin, \& Busalim, 2018).

Electronic word of mouth depends on the presence of product reviews (Tariq, Abbas, Abrar, \& Iqbal, 2018) and the need to share or retweet product details (Kim, Shawn, \& Adler, 2015; Chu \& Sung, 2015). In addition, the greater the tie strength has a positive effect on consumers' buying intentions for electronic word of mouth through social networking services (Chowdhury, 2016). Electronic word of mouth also is shown to have a significant effect on buying intention (Ladhari \& Michaud, 2015).

H11: E-WOM influences purchase intention.

\section{Brand Awareness}

The initial state of the complete awareness of the Brand starts from the fundamental recognition of the Brand to the intellectual rationale-based approach, which relies on the comprehensive data of the Brand (Petahiang, Mekel, \& Worang, 2015). Brand awareness is the possibility that customers will know about brand service, products, and all the characteristics of brands (Tariq, Abbas, Abrar, \& Iqbal, 2018). Brand recognition and the plethora of knowledge of the Brand and the organization (Jamali \& Khan, 2018).

Brand awareness indicators are brand communications created by both the firm and the consumer in social media and brand knowledge, including thinking, feeling, interpretation, pictures, and experience (Schivinski \& Dabrowski, 2015). In addition, continuous mutual interaction between the Brand and key influencers in online communities can increase the Brand's exposure (Wang, Hsiao, Yang, \& Hajli, 2016). A product with a higher brand image positively impacts customers' purchasing intention, which lets the business grow more robust on the market and helps to make profits (Shahid, Hussain, \& Azafar, 2017). Past research has shown that raising awareness of the Brand increases the likelihood of the Brand being purchased (Martins, Costa, Oliveira, Goncalves, \& Branco, 2019).

H12: Brand awareness influences purchase intention

\section{E. Brand Attitude}

Brand attitudes relate to the path, the intensity of awareness (Villiers, Chinimona, \& Chuchu, 2018), and the expressive element of consumers in the Brand's advertisement (Lee, Lee, \& Yang, 2017). It is a critical contact impact to produce the purchase of a brand. In addition, it is represented as an individual's evaluation of a noteworthy behavior, which is coupled with the discernible approval of a person as to the obvious implications of the actualization of behavior (Carnall, 2017).

Brand attitudes in social media are influenced by product branding (Lee, Lee, \& Yang, 2017). Moreover, the willingness to pay more and trust in the quality of the product is a form of customer brand attitude (Carnall, 2017). Previous studies have shown that the relationship 
between customer behavior and purchasing intention is especially important. The more optimistic customer perceptions towards such brands are, the more likely they are to buy (Yang, Al-Shaaban, \& Nguyen, 2014). Consumers ' brand attitudes, in turn, had a positive impact on their buying intention (Chen, Teng, Yu, \& Yu, 2016).

H13: Brand attitude influences purchase intention.

\section{F. Purchase Intention}

Purchase intention predicts future transactions by customers (Mohseni, Jayashree, Rezaei, \& Fevzi, 2018). Purchase intention means intending to purchase a product or receive services for future usage (Padhy \& Sawlikar, 2018). It also can be defined as an emotional judgment that works for a while later when buyer discernment of an individual's item or source matters (Khan, Rukhsar, \& Shoaib, 2016).

Many considerations affecting the purchase intention, one of them is the availability of websites which is extremely useful for consumers (Mohseni, Jayashree, Rezaei, Kasim, \& Okumus, 2016). Although the involvement of celebrities often influences the buying intent, consumers prefer to pay money for a well-known product (Hassana \& Jamil, 2014). Whereas purchase intention of products using green marketing, the social responsibility of the corporate is a crucial factor (Tulangow \& Kusumawardani, 2020). This study proposes several variables that determine the purchase intention, namely E-WOM, Brand Awareness, and Brand Attitude. The research framework is shown in Figure 1.

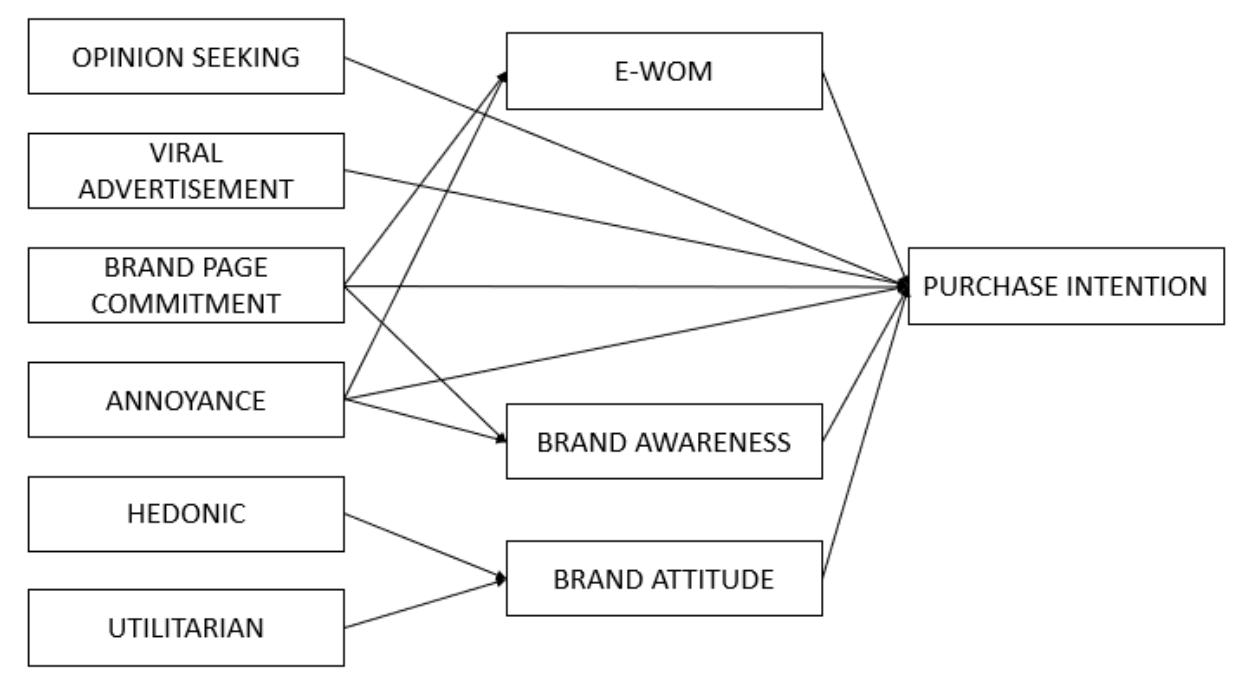

Figure 1 - Research Framework

\section{Method}

This study used a questionnaire that is modified based on the previous literature question. The instrument contains ten constructs: opinion Search, viral advertising, brand page commitment, irritation, hedonic, utilitarian, electronic word of mouth, brand recognition, brand attitude, and Purchasing intention. The level of agreement of the respondent has been indicated for each scale item using the Likert scale. The Likert scale is used to assess behaviors, beliefs, pressures, and expectations of an individual or a group of people about social phenomena.

A study population is usually a broad set of individuals or artifacts that are the focal point of a scientific question (Bickman, 1998). The population of this research is consumers 
188 Author Et Al. (2021) The Effect of Online Consumer Interaction and Shopping Motivation on Purchase Intention

who have ever purchase brand XYZ cosmetic products. The population is observed to be quite broad in every research study. Hence the study sample allows the research a realistic and representative population subset (Bickman, 1998). The sample of this research is millennials (18-35 years old) in greater Jakarta that have ever bought Brand XYZ products twice in the past six months and have ever seen Brand XYZ product reviews or advertisements on the social media platform. The sampling technique of the non-probability method used was purposive sampling. It was also used to select participants that matched the character of the population and objectives of the study.

Four hundred eighty questionnaires are spread using google form and send through online messengers and social media such as Line, WhatsApp, and Instagram. Every participant who finished fill in the online form will be automatically submitting the result to researcher emails. Next, the data will be exported through excel file, here researcher select respondent which are a match with the characteristic population. Finally, the researcher enters the valid data into SPSS 24 to analyze its validity and reliability and AMOS 25 for hypothesis testing. Researchers receive 390 participants who fulfill the questionnaire. However, 300 participants are matched with the criteria and usable for analysis.

Table 1 - Respondents' Demographic Profile

\begin{tabular}{llll}
\hline Demography & Category & $\mathrm{n}$ & $\%$ \\
\hline Gender & Female & 294 & 98 \\
& Male & 6 & 2 \\
\hline Age & $18-25$ & 240 & 80 \\
& $26-30$ & 38 & 12.7 \\
& $31-35$ & 22 & 7.3 \\
\hline Occupation & Employee & 72 & 24 \\
& Entrepreneur & 27 & 9 \\
& Freelancer & 5 & 1.7 \\
& Student & 196 & 65.3 \\
\hline Most Used social media & Facebook & 23 & 7.7 \\
& Instagram & 219 & 73 \\
& Snapchat & 5 & 1.7 \\
& Twitter & 16 & 5.3 \\
& YouTube & 37 & 12.3 \\
\hline Monthly Income/ Allowance & IDR 1-3 million & 148 & 49.3 \\
& IDR 3-10 million & 90 & 30 \\
& Less than IDR 1 million & 29 & 9.7 \\
& More than 10 million & 33 & 11 \\
\hline Cosmetic product purchase & More than once a month & 64 & 21.3 \\
& Once in a month & 85 & 28.3 \\
& Once within three months & 114 & 38 \\
frequency & Once within six months & 37 & 12.3 \\
\hline Most purchased cosmetic & Eye Product (brows, liner, shadow, etc.) & 119 & 39.7 \\
& Face Product (primer, foundation, powder, etc.) & 99 & 33 \\
& Lip Product (lipstick, lip balm, liner, etc.) & 82 & 27.3 \\
\hline
\end{tabular}

\section{Results and Discussions}

\section{A. Validity and Reliability}

A validity test is necessary to do in every research with the questionnaire method. Validity has the meaning of how far is the accuracy and precision of a questionnaire in performing the function of measuring (Taherdoost, 2016). In this research, face validity is used 
to be a valid measure of a given variable or construct (Kneebon \& Dewar, 2016). The content of this research adopts measurement from previous research and adjusted the questionnaire to be matched with the research topic. For the construct validity, convergent and discriminant are sufficient as the measurement without include criterion validity (Marcoulides \& Yuan, 2016). Factor analysis shows that a significance of 0.05 and Kaiser Mayer Olkin (KMO) and Bartlett's Test and a minimum factor loading value of more than 0.5 stated valid, and samples can be further investigated (Santoso, 2002).

Table 2 - KMO and Bartlett's Test Result

\begin{tabular}{lll}
\hline \multicolumn{2}{l}{ Kaiser-Meyer-Olkin Measure of Sampling Adequacy } & .948 \\
\hline $\begin{array}{l}\text { Bartlett's Test of } \\
\text { Sphericity }\end{array}$ & Approx. Chi-Square & 7449.438 \\
& & \\
& df & 780 \\
& Sig & .000 \\
\hline
\end{tabular}

From table 2 above, the result of the KMO test is 0.948 , and Bartlett's Test is .000 . This includes all variables in this research: opinion seeking, viral advertisement, annoyance, brand page commitment, hedonic, utilitarian, EWOM, brand attitude, brand awareness, and purchase intention. While the communalities of opinion seeking (0.658 until 0.701), viral advertisement (0.573 until 0.769$)$, brand page commitment (0.665 until 0.740$)$, annoyance ( 0.631 until 0.714 ), hedonic (0.565 until 0679), utilitarian (0.615 until 0.693$)$, electronic word of mouth $(0.667$ until 0.745), brand awareness (0.458 until 0.656), brand attitude (0.489 until 0.569), and purchase intention (0.513 until 0.613). Furthermore, the result of total variance experience of all variables, which is $65.103 \%$

Reliability testing is a questionnaire evaluation instrument that indicates a component or a construct (Taherdoost, 2016). A survey is declared reliable if somebody's response to a statement is consistent or constant over time (Siniscalco \& Auriat, 2005). In this study, the reliability coefficient was seen using Cronbach Alpha. If the reliability coefficient value is close to 1 , it means the question item meant more reliable. The minimum coefficient value that can show the question is reliable or not is $>0.6$.

Table 3 - Cronbach's Alpha Test Result

\begin{tabular}{lll}
\hline Variable & Cronbach's Alpha & N of items \\
\hline Opinion Seeking & 0.793 & 3 \\
Viral Advertisement & 0.859 & 5 \\
Brand Page Commitment & 0.906 & 5 \\
Annoyance & 0.860 & 5 \\
Hedonic & 0.813 & 3 \\
Utilitarian & 0.865 & 5 \\
E-WOM & 0.898 & 4 \\
Brand Awareness & 0.720 & 4 \\
Brand Attitude & 0.731 & 3 \\
Purchase Intention & 0.783 & 3 \\
\hline
\end{tabular}

Based on the reliability test table 3 above, all independent variables (opinion seeking = 0.793 , viral advertisement $=0.859$, brand page commitment $=0.906$, annoyance $=0.860$, hedonic $=0.813$, utilitarian $=0.865$ ), the mediating variable (electronic word of mouth $=0.898$, brand awareness $=0.720$, brand attitude $=0.731$ ) and the dependent variable (purchase intention $=0.783$ ) have Cronbach alpha $>0.60$. So that it can be concluded that all variables in this study are declared reliable. 
190 Author Et Al. (2021) The Effect of Online Consumer Interaction and Shopping Motivation on Purchase Intention

\section{B. Model Fit}

Using the SPSS AMOS Statistics software, the data were tested to assure model fit, which helps to determine whether the model adequately describes the data. The model fit criteria are $\mathrm{CMIN} \leq 5$, AGFI; AGI $\geq 0.9$, CFI; TLI; IFI $\geq 0.9$, RMSEA $<0.08$. Model fit result of this research indicated by the selected overall goodness-of-fit statistics: CMIN/DF $=1.621$, $\mathrm{GFI}=0.844, \mathrm{AGFI}=0.815, \mathrm{IFI}=0.939, \mathrm{TLI}=0.931, \mathrm{CFI}=0.939$, and $\mathrm{RMSEA}=0,46$. The RMSEA is slightly on the low side. However, it is still considered acceptable because 6 out of 7 criteria are fulfilled (Lei \& $\mathrm{Wu}, 2015$ ).

\section{Hypothesis Testing}

Hypothesis testing shows the strength of each influence, with criteria $\mathrm{CR} \geq 1.96$ and $\mathrm{P}$ values $\leq 0.05$ (Marcoulides \& Yuan, 2016). Lastly, multiple $\mathrm{R}$ square shows the extent to which the dependent variable is a predictor variable, and the closer its value to one, the better the relationship is. (Marcoulides \& Yuan, 2016). As seen in table 4, from 13 hypotheses, there are ten hypotheses accepted which are: opinion seeking influence purchase intention; brand page commitment influence brand awareness; annoyance influence electronic word of mouth; annoyance influence purchase intention; annoyance influence brand awareness; hedonic influence brand attitude; utilitarian influence brand attitude; electronic word of mouth influence purchase intention; and brand attitude influence purchase intention. Meanwhile, the 3hypothesis rejected are: viral advertisement influence purchase intention; brand page commitment influence purchase intention; and brand awareness influence purchase intention.

Table 4 - Hypothesis Testing Result

\begin{tabular}{lllll}
\hline Path & Estimate & CR & p-value & Decision \\
\hline $\mathrm{OS} \rightarrow$ PI & .290 & 3.988 & 0.000 & Supported \\
$\mathrm{VA} \rightarrow$ PI & .003 & 0.036 & 0.971 & Not Supported \\
$\mathrm{BPC} \rightarrow$ EWOM & .686 & 9.056 & 0.05 & Supported \\
$\mathrm{BPC} \rightarrow$ PI & .491 & -1.701 & 0.89 & Not Supported \\
$\mathrm{BPC} \rightarrow$ BA & .166 & 3.547 & 0.000 & Supported \\
$\mathrm{AN} \rightarrow$ EWOM & .240 & 3.504 & 0.000 & Supported \\
$\mathrm{AN} \rightarrow$ PI & .150 & 2.128 & 0.033 & Supported \\
$\mathrm{AN} \rightarrow$ BA & .192 & 4.032 & 0.000 & Supported \\
$\mathrm{HE} \rightarrow$ BT & .398 & 8.502 & 0.000 & Supported \\
$\mathrm{UT} \rightarrow$ BT & .192 & 3.435 & 0.000 & Supported \\
$\mathrm{EWOM} \rightarrow$ PI & .491 & 5.737 & 0.000 & Supported \\
$\mathrm{BA} \rightarrow$ PI & .068 & 0.439 & 0.661 & Not Supported \\
$\mathrm{BT} \rightarrow$ PI & .319 & 2.200 & 0.028 & Supported \\
\hline
\end{tabular}

\section{Multiple R Square}

$70 \%$ of the variation in purchase intention is explained by viral advertisement, brand page commitment, and hedonic. The result of the test shows $51.6 \%$ of the variation in brand attitude, $54.9 \%$ of the variation in brand awareness, $59.5 \%$ of the variation in utilitarian, $65.7 \%$ of the variation in annoyance, and $72.8 \%$ of the variation in electronic word of mouth. 


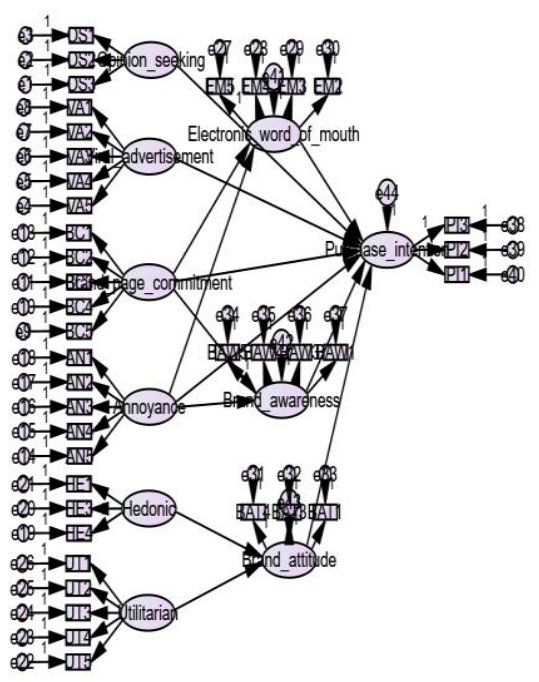

Figure 2 - Structural Model

\section{E. Discussion}

This study examines the relationship between consumer interaction (viral advertisement, opinion seeking, annoyance, and brand page commitment), shopping motivation (utilitarian and hedonic), E-WOM, brand attitude, brand awareness, and purchase intention on the consumer of beauty products. This study found that electronic word of mouth mediated brand page commitment and annoyance influence purchase intention. At the same time, brand attitude becomes the mediator of both hedonic and utilitarian. Purchase intention is also influenced directly by opinion seeking and annoyance.

Based on the hypothesis testing result, several variables from consumer interaction influence the purchase intention directly, which are opinion seeking and annoyance. Opinion seeking has a significant influence on purchase intention (CR 3.988; p-value <0.05). Consumers who participate in social media contacts are likely to feel positive about their purchase intention (Vecchi, 2017). This engagement process is seen as a way for consumers to consult opinions for decision reassurance (Goldsmiths \& Horowitz, 2013). Besides, annoyance also significantly influences purchase intention (CR 2.128; p-value 0.033). The content of social media that disturbs customers causes them to quickly turn against and not consider the Brand when making a purchase (Hutter, Hautz, Dennhardt, \& Füller, 2013).

This study found that brand page commitment does not significantly influence purchase intention (CR -1.701, p-value 0.89). Brand page commitment can lead to purchasing intention if consumers actively engage in the Brand's social media activities (Dessar, Veloutsou, \& Morgan-Thomas, 2015). Consumers prefer discussion in their language. However, Brand XYZ only has one Instagram official account, which uses English as the intermediate language. Brand XYZ has YouTube and Facebook as their official brand page, but around $73 \%$ of the respondent said they use Instagram the most, which means they are not committed to the brand page. However, brand page commitment is significantly influencing E-WOM (CR 9.056; pvalue <0.05) and brand awareness (CR 3.547; p-value <0.05). Electronic word of mouth is increase by strongly committed consumers of a brand. Consumers are likely to resist information that attacks or undermines the meaning of the Brand (Jafari, 2015). In addition, social media is one way to introduce customers to brands, and it follows that the more engaged 
192 Author Et Al. (2021) The Effect of Online Consumer Interaction and Shopping Motivation on Purchase Intention

consumers participate in social media brands, the greater the visibility of brands (Hutter, Hautz, Dennhardt, \& Füller, 2013).

Annoyance is found to be influencing E-WOM (CR 3.504; p-value <0.05), brand awareness (CR 4.032; p-value <0.05), and purchase intention (CR 2.128; p-value 0.033). Annoyance leads to negative effects on the overall fan page by spreading negative word of mouth (Hutter, Hautz, Dennhardt, \& Füller, 2013). The number of brand ads on social media that keep appearing, disturbing consumers, and make them to unsubscribes the brand social media. In that case, it describes the internet marketing for increasing brand awareness is hampered because of annoyance (Wulandari, 2017). In addition, the content of social media that irritates users leads them to turn against easily and not consider the Brand when making purchases (Hutter, Hautz, Dennhardt, \& Füller, 2013).

Another variable from consumer interaction that is not significantly influencing purchase intention directly is a viral advertisement (CR 0.036; p-value 0.971). Consumers exposed to the viral advertisement cannot be sure to affect purchase intention if they are not involved in the viral advertisement itself. Mostly, the respondent of this research did not actively take part or rarely comment, tag friends, and repost the viral advertisement content (Trivedi, 2017).

Both hedonic (CR 8.502; p-value <0.05) and utilitarian (CR 3.435; p-value <0.05) are significantly influencing the brand attitude. The Brand that can fulfill consumers' pleasure and desire of hedonism brings about a favorable attitude toward its Brand (Lee \& Hwang, 2011). Besides, consumers who get utilitarian benefits potentially enhance their attitude toward the Brand (Hartmann \& Apaolaza-Ibáñez, 2012).

Among three mediating variables, only two are influencing the purchase intention, which is E-WOM (5.737; p-value <0.05) and brand attitude (CR 2.200; p-value 0.028). Jalilvand \& Samiei (2015) found that consumers can read online recommendations of the product they are interested in through mobile Internet, which might have a strong impact on their purchase intention. Moreover, satisfied customers would positively affect the brand and influence customers' decision to purchase the products (Abzari, Ghassemi, \& Vosta, 2014). On the other hand, brand awareness is not significantly influencing purchase intention (CR 0.439; p-value 0.661). Brand awareness is the beginning step of a phase before customers decide to purchase. After passing brand awareness, consumers will pass the next phase: knowledge, liking, preference, conviction, and, finally, purchase (Hutter, Hautz, Dennhardt, \& Füller, 2015). In purchasing makeup products, there is usually a high involvement that happened between consumers and brands. Consumers tend to do research and compare makeup products first as it is affecting their looks. In this case, brand awareness is not necessarily influencing the purchase intention of Brand XYZ consumers.

\section{Conclusions and Recommendations}

\section{Conclusion}

This study investigates the antecedents of consumer purchase intention of beauty products in Indonesia through the role of E-WOM, Brand Awareness, and Brand Attitude. The authors believe that by investigating consumer interaction through various platforms and examining their shopping motivation, brands will predict the factors influencing their purchase. 
It is not only will improve the engagement with the consumer but also improving the sales. Based on the result of this study, it can be concluded:

- Opinion seeking and annoyance significantly influence purchase intention.

- Brand page commitment and annoyance significantly influence purchase intention through E-WOM as the mediator. Both variables are also significantly influencing brand awareness but do not lead to purchase intention.

- Both shopping motivations, hedonic and utilitarian, significantly influence the brand attitude, which leads to the purchase intention.

- Viral advertisement and brand page commitment are not significantly influencing purchase intention.

\section{Managerial Implication}

This study shows that brand page commitment has a significant influence on electronic word of mouth and leads to purchase intention. The most active social media platform in Indonesia is Instagram (Holmes, 2017). Therefore, the company should create their Indonesia Instagram official account to ease consumers' commitment to the Brand. Next, the company can trigger the consumers to be more engaged with the brand page by first write a better bio as a first impression. Second take advantage of the business tools by adding a business address, phone number, and email address. The third is to get more artistic by stick with a theme to make a memorable impact on individuals who visit the account (Michaels, 2018). Besides, create viral advertising can also be done to attract more potential customers by involving a well-known celebrity, as suggested by Nugraha, Kusumawardani, and Octavianie (2018).

\section{Research Limitation}

This study has a limitation that gives an opportunity for future research. The researcher suggests that future research add a new variable that influences purchase intention, such as perceived ease of use, trust, and risk (Dachyar \& Banjarnahor, 2017). Second, future research also can change the object with the current Indonesia biggest retail industries like a convenience store or fashion retailer (Stockdill, 2018). The third is expanding the population and respondents to be more representable.

\section{References}

Abzari, M., Ghassemi, R. A., \& Vosta, L. N. (2014). Analysing the effect of social media on brand attitude and purchase intention: the case of Iran Khodro company. Procedia Social and Behavioral Sciences, 143(1), 822-826.

Anderson, K. C., Knight, D. K., Pookulangara, S., \& Josiam, B. (2014). Influence of hedonic and utilitarian motivations on retailer loyalty and purchase intention: a facebook perspective. Journal of Retailing and Consumer Services, 21(5), 773-779. doi:10.1016/j.jretconser.2014.05.007

Baron, C. (2018, January 30). Number of internet users in the Asia Pacific region as of January 2018, by country (in millions). Retrieved February 10, 2019, from Statista: https://www.statista.com/statistics/265153/number-of-internet-users-in-the-asiapacific-region/

Baruah, T. D. (2012). Effectiveness of Social Media as a tool of communication and its potential for technology enabled connections: A micro-level study. International Journal of Scientific and Research Publications, 2(5), 1-10. 
194 Author Et Al. (2021) The Effect of Online Consumer Interaction and Shopping Motivation on Purchase Intention

Bell, R., \& Buchner, A. (2018). Positive Effects of Disruptive Advertising on Consumer Preference. Journal of Interactive Marketing, 41, 1-13.

Bickman, L. (1998). Handbook of Applied Social Research Methods. California: Sage Publications.

Carnall, C. (.-2. (2017). Awareness, Attitude and Purchase Intention's Influence on the Response to the Out of Stock of Organic Yoghurt. Porto: Universidade Catolica Portuguesa.

Chandrasekara, R. (2015). Social media as a marketing tool: a study with reference to first time voters in the university of Colombo. Kelaniya Journal of Management, 5(3), 43.

Chattaraj, D., Mazumder, R., \& Lahiri, S. (2018). Buying Behaviour of Herbal Cosmetics by Women Consumers: An Exploratory Study in Kolkata. Indian Journal of Marketing, $48(5), 8$.

Chen, J., Teng, L., Yu, Y., \& Yu, X. (2016). The effect of online information sources on purchase intentions between consumers with high and low susceptibility to informational influence. Journal of Business Research, 69(2), 467-475.

Cheong, S. k., \& Michalski, T. (2016). Asia Personal Care \& Cosmetics Market Guide 2016. The International Trade Administration: the U.S. Commercial Service and Industry \& Analysis, 4(2), 54.

Chowdhury, N. (.-6. (2016). Influence of Electronic Word of Mouth on Consumer Purchase Intention.

Chu, S.-C., \& Sung, Y. (2015). Using a consumer socialization framework to understand electronic word-of-mouth (eWOM) group. Electronic Commerce Research and Applications, 14(4), 251-260.

Cong, Y., \& Zheng, Y. (2017). A Literature Review of the Influence of Electronic Word-ofMouth on Consumer Purchase Intention. Open Journal of Business and Management, $5,543-549$.

Dachyar, \& Banjarnahor, L. (2017). Factors influencing purchase intention towards consumer-to-consumer e-commerce. Intangible Capital, 13(5), 946-968.

Dessar, L., Veloutsou, C., \& Morgan-Thomas, A. (2015). Consumer engagement in online brand communities: a social media perspective. Journal of Product \& Brand Management, 24(1), 28-42. doi:https://doi.org/10.1108/JPBM-06-2014-0635

Distaso, M. (2017, December 15). The science of influence: Social media's impact on four industries. Retrieved February 10, 2019, from Agility PR Solution: https://www.agilitypr.com/pr-news/public-relations/science-influence-social-mediasimpact-four-industries/

Etemad-Sajadi, R., \& Ghachem, L. (2015). The impact of hedonic and utilitarian value of online avatars on e-service. Computers in Human Behavior, 81-86.

Fransen, M. L., Verlegh, P. W., \& Smit, E. G. (2015). Typology of consumer strategies for resisting advertising, and a review of mechanisms for countering them. International Journal of Advertising, 34(1), 6-16.

Gallarza, M. G., Arteaga, F., Chiappa, G. D., \& Irene Gil Saura, M. B. (2017). A multidimensional service-value scale based on Holbrook's typology of customer value: Bridging the gap between the concept and its measurement. Journal of Service Management, 28(4), 724-762.

Goldsmiths, R. E., \& Horowitz, D. (2013). Measuring Motivations for Online Opinion Seeking. Journal of Interactive Advertising, 6, 2-14. doi:https://doi.org/10.1080/15252019.2006.10722114

Grosman, L. (2018, September 20). Beauty And Brains: Four Ways Cosmetics Companies Are Mastering Digital Marketing. Retrieved October 30, 2020, from Forbes: https://www.forbes.com/sites/forbescommunicationscouncil/2018/09/20/beauty-and- 
brains-four-ways-cosmetics-companies-are-mastering-digitalmarketing/\#1c41a65940ce

Gunawan, D. D., \& Huarng, K.-H. (2015). Viral effects of social network and media on consumers' purchase intention. Journal of Business Research, 68(11), 2237-2241.

Gvili, Y., \& Levy, S. (2016). Antecedents of attitudes toward eWOM communication: differences across channels. Internet Research, 26(1), 1030-1051.

Hartmann, P., \& Apaolaza-Ibáñez, V. (2012). Consumer attitude and purchase intention toward green energy brands: The roles of psychological benefits and environmental concern. Journal of Business Research, 65(9), 1254-1263.

doi:https://doi.org/10.1016/j.jbusres.2011.11.001

Hassana, S. R., \& Jamil, R. A. (2014). Influence of Celebrity Endorsement on Consumer Purchase Intention for Existing Products: A Comparative Study. Journal of Management Info, 4(1), 1-23.

Hayes, J., Shan, Y., \& Applequisr, J. (2016). Brand, interpersonal \& social network trust in viral advertising referral \& referral acceptance. Americal academy of advertising, conference, proceeding, 2(4), 130.

Holmes, R. (2017, March 23). Indonesia Economic Forum. Retrieved December 19, 2018 , from Most Active Social Media Platforms In Indonesia: http://www.indonesiaeconomicforum.com/article/infographic/most-active-socialmedia-platforms-in-indonesia-1

Hsu, J. L., \& Pann, J.-H. (2017). Subsequent Reaction to Online Advertisement Disturbance. International Journal of Business Administration and Management Research, 3(3), 2412-4346. doi:http://dx.doi.org/10.24178/ijbamr.2017.3.3.01

Hutter, K., Hautz, J., Dennhardt, S., \& Füller, J. (2013). The impact of user interactions in social media on brand awareness and purchase intention: the case of MINI on Facebook. Journal of Product \& Brand Management,, 22(6), 342-351.

Hutter, K., Hautz, J., Dennhardt, S., \& Füller, J. (2015). The impact of user interactions in social media on brand awareness. Journal of Product and Brand Management, 22(5), 342-351.

Jafari, S. M. (2015). The efect of brand commitment on e-wom and brand image in the mobile market. Research Journal of Applied Science, 10(10), 519-524.

Jalilvand, M. R., \& Samiei, N. (2015). The effect of electronic word of mouth on brand image and purchase intention: An empirical study in the automobile industry in Iran.

TMarketing Intelligence \& Planning, 30(4), 460-476. doi:https://doi.org/10.1108/02634501211231946

Jalonen, H., \& Jussila, J. (2016). Developing a Conceptual Model for the Relationship Between Social Media Behavior, Negative Consumer Emotions and Brand Disloyalty. Conference on e-Business, e-Services and e-Society (pp. 134-145). Swansea: Springer

Jamali, M., \& Khan, R. (2018). The impact of consumer interaction on social media on brand awareness and purchase intention: case study of samsung. Journal of marketing and logistics, 4(3), 114-127.

Jesse, M. (2016, March 23). Using integrated marketing to increase purchase intent. Retrieved 18 2, 2019, from Localsolution: http://blog.cmglocalsolutions.com/usingintegrated-marketing-to-increase-purchase-intent

Khan, S. K., Rukhsar, A., \& Shoaib, M. (2016). Influence of Celebrity Endorsement on Consumer Purchase Intention. IOSR Journal of Business and Management, 18(1), 6-9.

Khuong, M. N., \& Tran, T. B. (2015). Factors Affecting Impulse Buying toward Fashion Products in Ho Chi Minh City - A Mediation Analysis of Hedonic Purchase. 
196 Author Et Al. (2021) The Effect of Online Consumer Interaction and Shopping Motivation on Purchase Intention

International Journal of Trade, Economics and Finance, 6(4), 2-10. doi:10.7763/IJTEF.2015.V6.473

Kim, D., Shawn, S., \& Adler, J. H. (2015). What drives café customers to spread eWOM? International Journal of Contemporary Hospitality Management, 27(2), 261-282. doi:10.1108/IJCHM-06-2013-0269

Kneebon, I., \& Dewar, S. (2016). Reliability and validity of the Attributional Style Questionnaire- Survey in people with multiple sclerosis. Therapeutic Advances in Neurological Disorders, 10(1), 33-40.

Koch, O. F., \& Benlian, A. (2015). Promotional Tactics for Online Viral Marketing Campaigns: How Scarcity and Personalization Affect Seed Stage Referrals. Journal of Interacative Marketing, 32(1), 37-52.

Kronrod, A., \& Huber, J. (2018). Ad wearout wearout: How time can reverse the negative effect of frequent advertising repetition on brand preference. International Journal of Research in Marketing, 3(2), 2-18.

Lacroix, C., \& Jolibert, A. (2017). Mediational role of perceived personal legacy value between consumer agentic generativity and attitudes/buying intentions toward luxury brands. Journal of Business Research, 77(1), 203-211.

Ladhari, R., \& Michaud, M. (2015). eWOM effects on hotel booking intentions, attitudes, trust, and website perceptions. International Journal of Hospitality Management, 46(1), 36-45.

Lee, C.-H., \& Wu, J. J. (2017). Consumer Online Flow Experience: The Relationship Between Utilitarian and Hedonic Value, Satisfaction and Unplanned Purchase. Industrial Management \& Data Systems, 117(10), 2452-2467. doi:10.1108/IMDS-11201

Lee, E.-B., Lee, S.-G., \& Yang, C.-G. (2017). The Influences of Advertisement Attitude and Brand Attitude on Purchase Intention of Smartphone Advertising. Industrial Management \& Data Systems, 117(6), 1011-1036. doi:10.1108/IMDS-06-2016-02

Lee, J. H., \& Hwang, J. (2011). Luxury marketing: The influences of psychological and demographic characteristics on attitudes toward luxury restaurants. International Journal of Hospitality Management, 30(3), 658-669. doi:https://doi.org/10.1016/j.ijhm.2010.12.001

Lei, P. W., \& Wu, Q. (2015). Introduction to Structural Equation Modeling: Issues and Practical Consideration. Educational Measurement: Issues and Practice, 26(3), 33-43. doi:https://doi.org/10.1111/j.1745-3992.2007.00099.x

Leung, X. Y., Bai, B., \& Stahura, K. A. (2015). The Marketing Effectiveness of Social Media in the Hotel Industry: A Comparison of Facebook and Twitter. Journal of Hospitality \& Tourism Research, 39(2), 147-169.

López, M., \& Sicilia, M. (2014). eWOM as Source of Influence: The Impact of Participation in eWOM and Perceived Source Trustworthiness on Decision Making. Journal of Interactive Advertising, 14(2), 86-97. doi:10.1080/15252019.2014.944288

Lou, L., \& Koh, J. (2016). Is social advertising affective? influence of brand content on brand purchase intention and brand information diffusion. Research-in-progress papers, $3(1), 40$.

Ma, L., Lee, C. S., \& Goh, D. H.-L. (2015). Understanding news sharing. Online Information Review, 38(5), 598-615. doi:10.1108/OIR-10-2013-0239

Marcoulides, K., \& Yuan, K. H. (2016). New Ways to Evaluate Goodness of Fit: A Note on Using Equivalence Testing to Assess Structural Equation Models. Structural Equation Modeling: A Multidisciplinary Journal, 24(1), 148-153. 
Martins, J., Costa, C., Oliveira, T., Goncalves, R., \& Branco, F. (2019). How smartphone advertising influences consumers' purchase intention. Journal of Business Research, 94(1), 378-387.

Michaels, V. (2018, January 23). The next web. Retrieved December 19, 2018, from 10 ways to engage with your customers on Instagram: https://thenextweb.com/contributors/2018/01/23/10-ways-engage-customersinstagram/

Mohseni, S., Jayashree, S., Rezaei, S., \& Fevzi, A. K. (2018). Attracting tourists to travel companies' websites: the structural relationship. Current Issues in Tourism, 21(6), 616-645. doi:10.1080/13683500.2016.1200539

Mohseni, S., Jayashree, S., Rezaei, S., Kasim, A., \& Okumus, F. (2016). Attracting tourists to travel companies' websites: the structural relationship between website brand, personal value, shopping experience, perceived risk and purchase intention. Current Issues in Tourism, 21(6), 616-645. doi:10.1080/13683500.2016.1200539

Moon, M. M., Awanc, H., Attiqd, S., Rasool, H., \& Kiran, M. (2017). Consumer's perceptions of website's utilitarian and hedonic attributes and online purchase intentions: A cognitive-affective attitude approach. Spanish Journal of Marketing, 21(2), 73-88. doi:10.1016/j.sjme.2017.07.001

Mundel, J., Huddleston, P., Behe, B., Sage, L., \& Latona, C. (2018). An eye tracking study of minimally branded products: hedonism and branding as predictors of purchase intentions. Journal of Product \& Brand Management, 27(2), 146-157.

Nugraha, R., Kusumawardani, K. A., \& Octavianie, V. (2018). The Influence of Celebrity Endorsement in Instagram towards Customer Behavior and Purchase Intention in Healthy Food Diet Business. FIRM, 1-24. doi:10.33021/firm.v3i2.476

Padhy, S. K., \& Sawlikar, R. (2018). The Role of Brand Equity And Brand Awareness on Consumers' Purchase Intention. International Journal of Business and Management Invention, 12-16.

Pandey, S. K., \& Khare, A. (2015). Mediating role of opinion seeking in explaining the relationship between antecedents and organic food purchase intention. Journal of Indian Business Research, 7(4), 321-337.

Pandolph, S. (2018, January 28). The Social Commerce Report: How Facebook, YouTube, Pinterest, and other popular apps are upending the e-commerce space. Retrieved February 10, 2019, from Business Insider Singapore: https://www.businessinsider.sg/social-commerce-report-2018-1/?r=US\&IR=T

Pappu, R., \& Quester, P. (2016). How does brand innovativeness affect brand loyalty? European Journal of Marketing, 50(1/2), 2-28.

Paquette, H. (2013). Major Papers by Master Science Students. Retrieved October 30, 2020, from DigitalCommons@URI: http://digitalcommons.uri.edu/tmd_major_papers

Patil, R. (2015). Social Media - History and Components. IOSR Journal of Business and Management, 7(1), 69.

Perreault, M. C., \& Mosconi, E. (2018). Social Media Engagement: Content Strategy and Metrics Research Opportunities. the 51 st Hawaii International Conference on System Sciences (pp. 3568-3577). Hawaii: Scholar Space. doi:10.24251/HICSS.2018.451

Petahiang, I. L., Mekel, P., \& Worang, F. G. (2015). The Influence of Brand Awareness and Perceived Risk Toward Consumer Purchase Intention on Online Store. Jurnal Berkala Ilmiah Efisiensi, 15(4), 481-491.

Rezaei, S., Ali, F., Amin, M., \& Jayashree, S. (2016). Online impulse buying of Tourism Products. Journal of Hospitality and Tourism Technology, 60 - 83.

Salpini, C. (2017, August 23). Study: Instagram influences almost 75\% of user purchase decisions. Retrieved October 30, 2020, from Retail Dive: 
198 Author Et Al. (2021) The Effect of Online Consumer Interaction and Shopping Motivation on Purchase Intention

https://www.retaildive.com/news/study-instagram-influences-almost-75-of-userpurchase-decisions/503336/

Santoso, S. (2002). SPSS Versi 11.5 Cetakan Kedua. Jakarta: Gramedia.

Schivinski, B., \& Dabrowski, D. (2015). The impact of brand communication on brand equity through Facebook. Journal of Research in Interactive Marketing, 9(1), 31-53. doi:10.1108/JRIM-02-2014-0007

Seo, J. Y., Yoon, S., \& Vangelova, M. (2015). Shopping Plans, Buying Motivations and Return Policies: Impacts on Product Returns and Purchase Likelihoods. Marketing Letters, 27(4), 645-659.

Shahid, Z., Hussain, T., \& Azafar, F. (2017). The Impact of Brand Awareness on The consumers' Purchase Intention. Journal of Marketing and Consumer Research, 33, 3438.

Shaw, A. (2018, May 11). How Social Media Can Move Your Business Forward. Retrieved February 2, 2019, from Forbes:

https://www.forbes.com/sites/forbescommunicationscouncil/2018/05/11/how-socialmedia-can-move-your-business-forward/\#265037ee4cf2

Shi, S. (2014). Investigating trust and commitment on brand pages in social networking sites: the antecedents and outcomes. Hong Kong: Hong Kong Baptist University. Retrieved from https://repository.hkbu.edu.hk/etd_oa/21

Siniscalco, M. T., \& Auriat, N. (2005). Quantitative research methods in educational planning. France: UNESCO International Institute for Educational Planning.

Siswaningsih, N., \& Halim, E. (2018). The Impact of User Interactions in Social Media on Brand Awareness and Purchase Intention. International Conference on Applied Business and Economics (pp. 198-204). Jakarta: Universitas Borobudur.

Stemler, S. E. (2015). Content Analysis. Emerging Trends in the Social and Behavioral Sciences, 2(1), 1-14.

Stockdill, R. (2018, September 27). Inside Retail Asia. Retrieved December 20, 2018, from Euromonitor ranks Indonesia's top 10 retailers: https://insideretail.asia/2018/09/27/euromonitor-ranks-indonesias-top-10-retailers/

Taherdoost, H. (2016). How to Test the Validation of a Questionnaire/Survey in a Research. Validity and Reliability of The Research Instrument, 7(2), 13-40.

Tajvidi, M., Wang, Y., Haijli, N., \& Love, P. E. (2017). Brand value Co-creation in scial commerce: The role of interactivity, social support, and relationship quality. Computers in Human Behavior, 6, 24-50. doi:10.1016/j.chb.2017.11.006

Tanttu, T. (2017). Measuring Consumer Brand Engagement On Social Media With Annoyance As A Moderator. Jyväskylä: University Of Jyväskylä.

Tariq, M., Abbas, T., Abrar, M., \& Iqbal, A. (2018). EWOM and brand awareness impact on consumer purchase intention: mediating role of brand image. Pakistan Administrative Review, 1(1), 84-102.

Trivedi, J. P. (2017). The Effect of Viral Marketing Messages on Consumer Behaviour. Journal of Management Research, 17(2), 84-98.

Tulangow, G. D., \& Kusumawardani, K. A. (2020). Green is the New Black: The Role of Green Marketing Awareness and Perceived Innovation in the Fast Fashion Industry. The 4th International Conference on Family Business and Entrepreneurship (pp. 180203). Bekasi: President University.

Vecchi, A. (2017). Advanced Fashion Technology and Operations Management. London: Igi Global.

Vianna, K. A., de Mesquita, J. M., Linhares, M. R., \& Moreira, P. d. (2016). The Relationship Between Viral Marketing, Purchase Intention, and Brand Visibility: Study with 
Brazilian Customers. Proceedings of the 2015 Academy of Marketing Science (AMS) World Marketing Congress. 1, pp. 229-241. Bari: Springer.

Villiers, M. D., Chinimona, R., \& Chuchu, T. (2018). The Influence of Store Environment on Brand Attitude, Brand Experience and Purchase Intention. South African Journal of Business Management, 3(2), 10-15. doi:10.4102/sajbm.v49i1.186

Wang, E. S.-T. (2015). Different Effect of Utilitarian and Hedonic Benefits of Retail Food Packaging on Perceived Product Quality and Purchase Intention. Journal of Food Products Marketing, 1(1), 239-250. doi:10.1080/10454446.2014.885867

Wang, Y., \& Yu, C. (2017). Social interaction-based consumer decision-making model in social. International Journal of Information Management, 37(3), 179-189.

Wang, Y., Hsiao, S.-H., Yang, Z., \& Hajli, N. (2016). The impact of sellers' social influence on the co-creation of innovation with customers. Industrial Marketing Management, 54(1), 56-70. doi:10.1016/j.indmarman.2015.12.008

Widyanto, H. A., Kusumawardani, K. A., \& Septyawanda, A. (2020). Encouraging Behavioral Intention To Use Mobile Payment: An Extension Of Utaut2. Jurnal Muara Ilmu Ekonomi dan Bisnis, 4(1), 87-97.

Wulandari, N. R. (2017). Influence analysis in the use of social media in brand awareness and consumer purchase study online shop Nina's cake shop store. Economic and Business Faculty, 36(2), 73-83.

Yang, M., Al-Shaaban, S., \& Nguyen, T. B. (2014). Consumer Attitude and Purchase Intention towards Organic Food: A quantitative study of China. Kalmar: Linnæus University.

Yeh, C. H., Wang, Y. S., \& Yieh, K. (2016). Predicting smartphone brand loyalty: Consumer value and consumer-brand identification perspectives. International Journal of Information Management, 36(1), 245-257.

Yunus, N. H., Ariff, M. S., Som, N. M., Zakuan, N., \& Sulaiman, Z. (2016). The Mediating Effect of Brand Image between Electronic Word of Mouth and Purchase Intention in Social Media. Advanced Science Letter, 22(1), 3176-3180. doi:10.1166/asl.2016.7999

Yusuf, A., Hussin, A. C., \& Busalim, A. (2018). Influence of e-Wom Engagement in Social Commerce. Journal of Service Marketing, 32(4), 493-504. doi:10.1108/JSM-01-20170031

Zablocki, A., Schlegelmilch, B., \& Houston, M. (2016). How valence, volume and variance of online reviews influence brand attitudes. Ams Review, 23(1), 1-17.

Zhang, K. Z., Benyoucef, M., \& Zhao, S. (2016). Building brand loyalty in social commerce: The case of brand microblogs. Electronic Commerce Research and Applications, 15, 14-25. doi:10.1016/j.elerap.2015.12.001 
200 Author Et Al. (2021) The Effect of Online Consumer Interaction and Shopping Motivation on Purchase Intention

Appendix 1.

Questionnaire items

\begin{tabular}{ll}
\hline Variable & Item Statement \\
\hline \multirow{3}{*}{ Opinion } & When I consider Brand XYZ new products, I ask my contacts on the social \\
Seeking & I like to get my contacts' opinions on the social media before I buy Brand \\
& XYZ products \\
& I feel more comfortable choosing Brand XYZ products when I have gotten \\
& my contacts' opinions on them on social media \\
\hline & Viral marketing messages from Brand XYZ are a good source of up to date \\
& product information \\
& Viral marketing message from Brand XYZ is a convenient source of \\
& product information \\
Viral & Viral marketing messages from Brand XYZ are a decent source of product \\
Advertisement & information \\
& I would consider passing along viral advertising to someone I know. \\
& I would recommend my friends and family to participate in an interesting \\
& Social Media viral advertising campaign. \\
\hline & I am sure that there are no other brand pages where I could find the same \\
& content and experience that I get on Brand XYZ social media. \\
& I feel a strong sense of belonging to Brand XYZ's social media. \\
& The relationship that I have with Brand XYZ is something I am very \\
committed to. & The relationship that I have with Brand XYZ is something I intend to \\
Brand Page & maintain indefinitely. \\
Commitment & The relationship that I have with Brand XYZ is deserving my maximum \\
& effort to maintain.
\end{tabular}

I think it is disturbing if my social media feed is overloaded with social media content published by the Brand

Annoyance I think it is disturbing if the same content of the Brand is brought forward multiple times

I think it is disturbing if Brand XYZ posts product ads all the time

I am annoyed to Brand XYZ pop up ads in the web page

I am annoyed with Brand XYZ Floating ads at sides of web page

Browsing on Brand XYZ social media is truly a joy.

Hedonic The interaction with the other Brand XYZ consumer is pleasant I enjoy browsing Brand XYZ social media to forget my problem

Purchasing Brand XYZ products online can increase my shopping efficiency

Utilitarian $\quad$ Shopping Brand XYZ products via online very convenient for me Purchasing Brand $X Y Z$ products online makes shopping much simpler.

Purchasing Brand XYZ products online are functional.

Purchasing Brand $X Y Z$ product via online are practical

Electronic

Word of

I would like to post about this Brand XYZ product on my personal social

Mouth media

I would like to add information about this Brand XYZ product to my personal social media 
I would like to update my personal social media about Brand XYZ products in the future.

I have retweeted/repost the links of Brand XYZ product

Several characteristics of Brand XYZ instantly come to my mind

Brand Brand XYZ is often at the top of the minds of the potential customer firms

Awareness when they think of our product category

The name of Brand XYZ is well known among potential customers

Product branding in Brand $X Y Z$ advertisements is good.

Brand Attitude

Product branding in Brand XYZ advertisements is pleasant.

Product branding in Brand XYZ advertisements is favourable.

I have more confidence on the quality of Brand $\mathrm{XYZ}$

I am willing to pay more for Brand XYZ

Purchase

I am likely to purchase Brand XYZ on the website

Intention

I will use online channel to purchase Brand $X Y Z$ in the future

I will consider the website as first choice for purchasing Brand XYZ 